\title{
Modeling climate change, urbanization, and fire effects on Pinus palustris ecosystems of the southeastern U.S.
}

\author{
Jennifer K. Costanza ${ }^{\mathrm{a},{ }^{*}, \text { Adam J. Terando }}{ }^{\mathrm{b}, \mathrm{c}}$, Alexa J. McKerrow ${ }^{\mathrm{d}}$, Jaime A. Collazo ${ }^{\mathrm{e}}$ \\ a North Carolina Cooperative Fish and Wildife Research Unit, Department of Applied Ecology, North Carolina State University, Campus Box 7617, Raleigh, NC \\ 27695, USA \\ b Southeast Climate Science Center, U.S. Geological Survey, Campus Box 7617, Raleigh, NC 27695, USA

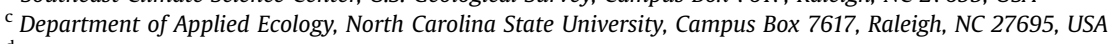 \\ ' Core Science Analytics and Synthesis, U.S. Geological Survey, Campus Box 7617, Raleigh, NC 27695, USA \\ e U.S. Geological Survey, North Carolina Cooperative Fish and Wildife Research Unit, Department of Applied Ecology, North Carolina State University, \\ Campus Box 7617, Raleigh, NC 27695, USA
}

\section{A R T I C L E I N F O}

\section{Article history:}

Received 28 April 2014

Received in revised form

11 December 2014

Accepted 14 December 2014

Available online

\section{Keywords:}

Climate-resilient

Conservation

Open-canopy longleaf

State-and-transition simulation model

Urban growth

\begin{abstract}
A B S T R A C T
Managing ecosystems for resilience and sustainability requires understanding how they will respond to future anthropogenic drivers such as climate change and urbanization. In fire-dependent ecosystems, predicting this response requires a focus on how these drivers will impact fire regimes. Here, we use scenarios of climate change, urbanization and management to simulate the future dynamics of the critically endangered and fire-dependent longleaf pine (Pinus palustris) ecosystem. We investigated how climate change and urbanization will affect the ecosystem, and whether the two conservation goals of a $135 \%$ increase in total longleaf area and a doubling of fire-maintained open-canopy habitat can be achieved in the face of these drivers. Our results show that while climatic warming had little effect on the wildfire regime, and thus on longleaf pine dynamics, urban growth led to an $8 \%$ reduction in annual wildfire area. The management scenarios we tested increase the ecosystem's total extent by up to $62 \%$ and result in expansion of open-canopy longleaf by as much as $216 \%$, meeting one of the two conservation goals for the ecosystem. We find that both conservation goals for this ecosystem, which is climateresilient but vulnerable to urbanization, are only attainable if a greater focus is placed on restoration of non-longleaf areas as opposed to maintaining existing longleaf stands. Our approach demonstrates the importance of accounting for multiple relevant anthropogenic threats in an ecosystem-specific context in order to facilitate more effective management actions.
\end{abstract}

() 2014 Elsevier Ltd. All rights reserved.

\section{Introduction}

Understanding how ecosystems will respond to future anthropogenic drivers such as climate change is critical to management for resilience and sustainability (Millar and Woolfenden, 1999; Stein et al., 2013). In ecosystems in which wildfire is a fundamental process, knowing how climate change could alter future wildfire regimes is key to developing conservation and management strategies that promote persistence over time and space (Stephens et al., 2013). Recent studies suggest that future changes

\footnotetext{
* Corresponding author. Present address: Department of Forestry and Environmental Resources, North Carolina State University, 3041 Cornwallis Road, Research Triangle Park, NC 27709, USA.
}

E-mail address: jennifer_costanza@ncsu.edu (J.K. Costanza). in climate could have substantial impacts on wildfire regimes, resulting in major ecosystem impacts (Overpeck et al., 1990; Dale et al., 2001; IPCC, 2007). Climate change is already affecting wildfires in some cases. For example, in the western U.S., earlier snowmelt due to recent increases in spring and summer temperatures have led to higher wildfire activity, and this trend is expected to become more pronounced in the future (Westerling et al., 2006; Litschert et al., 2012). However in other regions, climate change is likely to lead to a decrease in wildfire activity (Moritz et al., 2012). This uncertainty in the magnitude and direction of wildfire responses to climate change limits any generalized predictions across ecosystems that could be used to inform management strategies.

In addition to affecting ecosystems, climate change acts in concert with other drivers, including land use conversion (Staudt et al., 2013). In particular, conversion to urban and suburban land 
uses is a major driver of ecosystem change worldwide and may be more important than global climate change in some regions (Grimm et al., 2008). Conversion to urban land uses affects a variety of ecosystem properties, including water quality and predator-prey relationships (Anderies et al., 2007; Tu, 2013). In addition, urbanization can affect wildfire dynamics as well as the ability to conduct prescribed fires (Costanza et al., 2013; Hawbaker et al., 2013). Of particular concern is how the combination of climatic and land use changes will affect the role of fire in fire-dependent ecosystems. However, to date, few studies have undertaken the detailed accounting of all of the primary anthropogenic drivers that is necessary to better predict the consequences of climate and land use change in fire-dependent ecosystems (one exception is Paveglio et al. (2013)). A better understanding of how these multiple drivers will affect wildfires will allow for more effective management.

Here we investigate how a rapidly warming and urbanizing world affects the critically endangered longleaf pine ecosystem that is dependent on wildfire and fire management. This ecosystem, located in the southeastern U.S. from southern Virginia to Texas, and named after the keystone tree species (Pinus palustris), is particularly sensitive to changes in fire frequency. Low severity but highly frequent fires help to maintain the open, park-like savanna structure that provides habitat for a rich diversity of plant and animal species. However, the majority of wildfires in the ecosystem have been suppressed in recent years through direct human action or indirectly through land use change (Frost, 2006). A combination of wildfire suppression, timber harvesting, and land conversion has resulted in a severely degraded and fragmented system which is now only found over about 3\% of its historic range (Frost, 1993; VanLear et al., 2005). With this degradation has come declines in the species that are strongly dependent on this ecosystem, including the federally-endangered Red-cockaded Woodpecker (U.S. Fish and Wildlife Service, 2003). In response, widespread improvement of degraded stands via prescribed burning, as well as restoration of converted stands using prescribed burning combined with other management actions have been proposed (VanLear et al., 2005; America's Longleaf, 2009). Specifically, a major conservation goal for the longleaf pine ecosystem is a doubling of the extent of fire-maintained, open longleaf stands (from 1.5 million ha to 3 million ha), and increasing the total extent of the longleaf pine ecosystem by $135 \%$ (from 3.4 million ha to 8.0 million ha) (America's Longleaf, 2009).

To plan for and accomplish this ambitious conservation goal, resource managers need information about the future role of both wildfires and managed fires in the longleaf pine ecosystem. Because wildfire suppression is extensive in the Southeast, prescribed burning is currently the major means by which fires affect the longleaf pine ecosystem, and is the primary strategy for maintaining and restoring the ecosystem. In fact, more prescribed burning is conducted in the Southeast than any other region of the country (Haines et al., 2001). However, current prescribed burning management programs still do not implement enough burning to accomplish ecosystem-wide restoration of longleaf pine (VanLear et al., 2005; Costanza et al., 2013). Several regional initiatives have begun to address ways to implement more burning over larger extents in the Southeast (Southeastern Regional Working Group, 2012). Recent plans suggest doubling current burning levels, with primary emphasis on maintaining open longleaf stands, and a secondary goal to improve and restore degraded stands (America's Longleaf, 2009). However, decision makers need to know whether proposed management strategies to double prescribed burning efforts and focus on maintaining open stands will be sufficient given possible future climatic and land use changes. For example, an altered wildfire regime in the longleaf pine ecosystem due to climate change could make management more difficult, especially if wildfires become more frequent. Wildfires in long-unburned areas where fuels have built up due to past fire suppression could lead to undesired effects such as high mortality of longleaf pine trees (Varner et al., 2005, 2007). In addition, growth of urban areas will lead to permanent conversion of longleaf and other habitats, which cannot be restored.

In this study, we simulated the future effects of potential prescribed burning regimes on the longleaf pine ecosystem in a landscape subject to the anthropogenic drivers of climate change and urban growth. We first examined how greenhouse gas emissions trajectories and urban growth would affect the wildfire regime. Our wildfire projections were developed by exploiting the observed relationship between climate and wildfire to build an empirical model that was deployed in a suite of climate models. We next simulated scenarios of prescribed burning in the context of climate change and urban growth. Our prescribed burning scenarios varied both the annual amount of burning and the extent to which the focus of burning was on maintaining open longleaf stands versus restoring fire-suppressed stands. We asked these questions:

1. What effect could climate change and urbanization have on the fire regime in longleaf pine stands, and how will the amount of fire-maintained, open longleaf pine change as a result?

2. Can recommended prescribed burning strategies achieve conservation goals for the longleaf pine ecosystem given these drivers?

The results of this research will help inform whether proposed management strategies focused on prescribed burning are likely to be successful in accomplishing their goals of doubling the extent of open, fire-maintained longleaf stands and more than doubling the total extent of the ecosystem. Thus, our work will provide critical information for sustainable management of the longleaf pine ecosystem and the species that depend on it.

\section{Methods}

\subsection{Study area}

We modeled longleaf pine dynamics across a portion of the Southeast Coastal Plain of the U.S. that corresponds to the Dougherty Plain ecoregion (EPA, 2004). This region covers 2.94 million ha $\left(29,400 \mathrm{~km}^{2}\right)$ in portions of southwestern Georgia (GA), southeastern Alabama (AL) and the Florida (FL) Panhandle (Fig. 1). Longleaf pine ecosystems cover $9 \%$ of the study area (Southeast Gap Analysis Project (SEGAP), 2008). Agricultural lands (row crops and pastures) and loblolly pine (Pinus taeda) plantations are the most abundant land cover types in the region today, comprising $42 \%$ and $23 \%$ of the landscape, respectively (SEGAP, 2008). Agriculture and pine plantations are predominant across much of the Southeast; therefore, reestablishing longleaf in those areas will be particularly important for longleaf pine restoration efforts. The remaining portions of the study area are a mixture of other plant communities, including bottomland hardwood forests. A majority of the region is privately owned (96\%), with the public land occurring in relatively small state management areas, mainly along rivers.

The study area within the Southeast Coastal Plain experiences a humid continental climate. Mean monthly temperatures range from $9.4^{\circ} \mathrm{C}$ in January to $27.5^{\circ} \mathrm{C}$ in July while maximum precipitation occurs in July ( $5 \mathrm{~mm}$ /day) with a slight minimum occurring in the spring ( $2.9 \mathrm{~mm} /$ day in May). As with almost all areas of the planet, significant warming is projected to occur in the 21 st century. Results from an ensemble of statistically downscaled global climate models (Stoner et al., 2012) show average daily maximum 


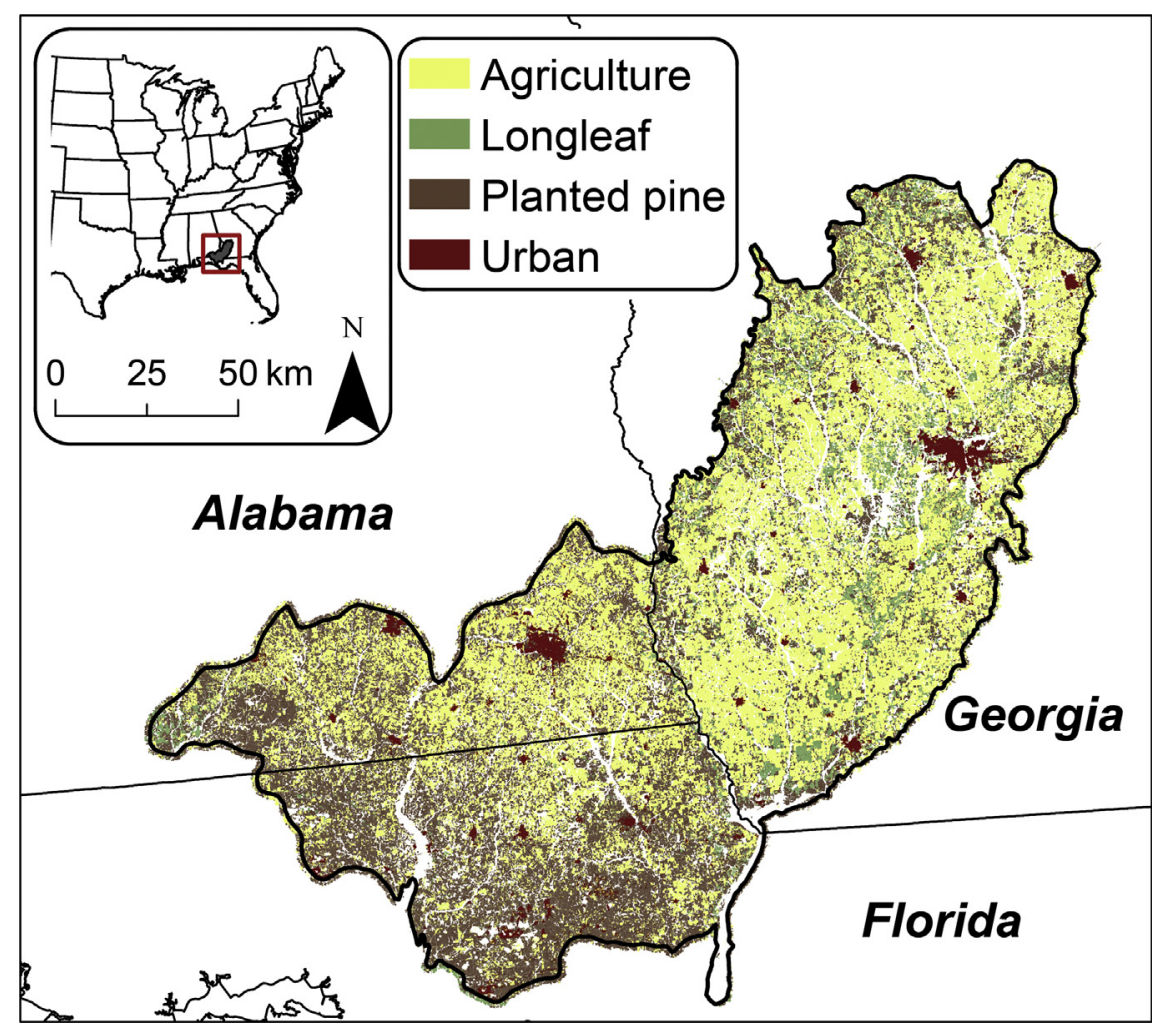

Fig. 1. Study area in the Dougherty Plain ecoregion. The agriculture, longleaf, and planted pine polygons we mapped and simulated are shown, along with urban areas.

temperatures increasing $2.1^{\circ} \mathrm{C}$ by the end of the century for a low greenhouse gas (GHG) emissions scenario, and $3.7{ }^{\circ} \mathrm{C}$ for a high GHG emissions scenario (Fig. 2). Average daily minimum temperatures are projected to increase 2.2 and 4.7 under low and high emissions scenarios, respectively (Fig. 2). Moderate increases in precipitation are projected, but the spread amongst models is large, owing to the greater uncertainty in the magnitude and direction of the regional precipitation response to increasing GHGs (Fig. 2).

A small portion of the study area (6\%) is currently mapped as urban. Most of the developed areas in the region occur in and around small cities like Albany and Bainbridge, Georgia and Dothan, Alabama. The total population of the counties in the study area in 2010 was 528,000 (U.S. Census Bureau, 2011). The combined population of the region is projected to increase $12 \%$ by 2030 , but 20-30\% population growth is projected in counties surrounding Albany and Dothan (University of Alabama Center for Business and Economic Research (CBER), 2012; Georgia Governor's Office of Planning and Budget, 2013; University of Florida Bureau of Economic and Business Research, 2013). While only a modest amount of population growth is expected in the region, conservative projections indicate that the areal footprint of urban land in the region could expand by $60 \%$ over its current extent by 2030 , and four-fold over its current extent by 2100 (Terando et al., 2014). This sprawling, fragmented development is the dominant pattern of urbanization in the Southeast, especially in more rural counties (Kaza, 2013).

\subsection{Modeled scenarios of longleaf pine conservation and restoration}

To simulate the future fire regime in the longleaf pine ecosystem, we constructed 14 management scenarios based on policy-relevant combinations of four factors. The factors we varied were the GHG emissions trajectory, the urban extent, the total annual area burned by prescribed fire, and the allocation of management actions (Table 1). We provide an overview of the scenarios in this section. Details of the simulation model and the resulting differences among scenarios and management actions are given in Section 2.3.

To address our first research question about the effect of climate change and urbanization on the fire regime in the longleaf pine ecosystem, we modeled six scenarios that did not incorporate management, but varied by degree of climate warming (three treatments) and urbanization (two treatments). Our climate change treatments included wildfire probabilities under one low and one high GHG emissions trajectory from the Intergovernmental Panel on Climate Change Fourth Assessment Report (Nakićenović and Swart, 2000), as well as no change in climate. The low emissions scenario (B1) assumes that the world economy will grow, but clean and resource efficient technologies will be adopted, along with global solutions to economic, social and environmental pressures. The high emissions scenario (A1FI) assumes very rapid economic growth along with an emphasis on fossil fuels. This scenario tracks most closely with the current trajectory of fossil fuel emissions. One of our urbanization treatments was selected from recent urban growth projections for the region (Terando et al., 2014), and the other assumed no growth in urban areas in the future. While scenarios that include no climate change and no urbanization likely do not represent plausible futures, they enable comparisons with other urbanization and climate change scenarios to better isolate the effects of climate change and urbanization.

To answer our second question about whether recommended prescribed burning strategies can achieve their goals in the face of urbanization and climate change, we modeled eight additional scenarios that included management via prescribed burning (Table 1). The eight management scenarios varied in the levels and 
(a)

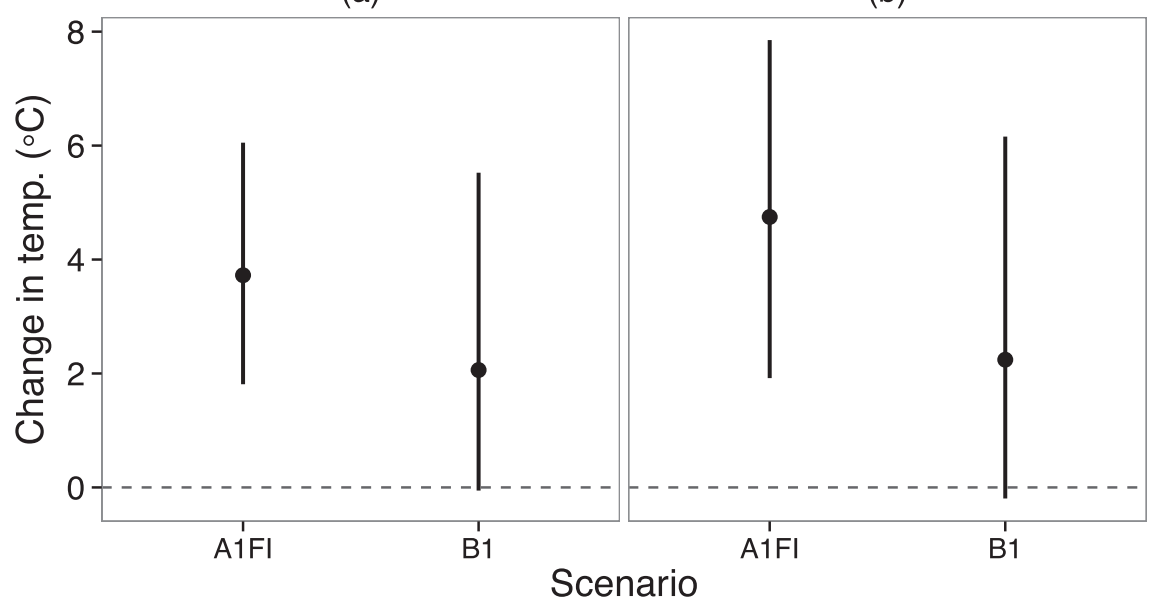

(c)

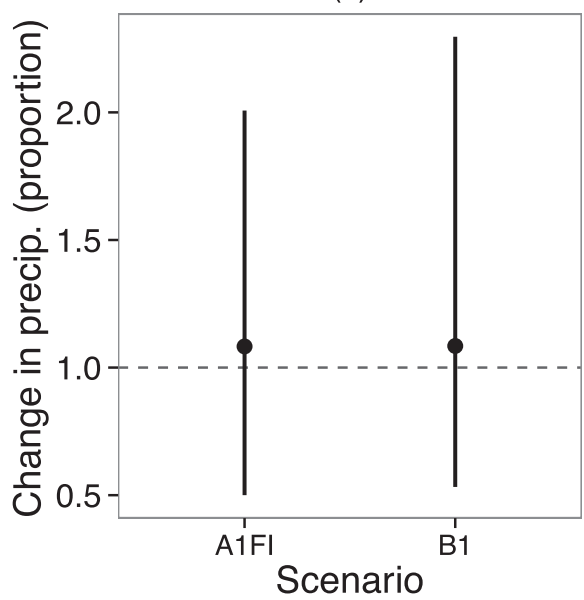

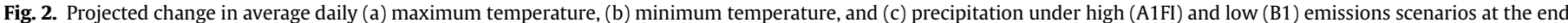

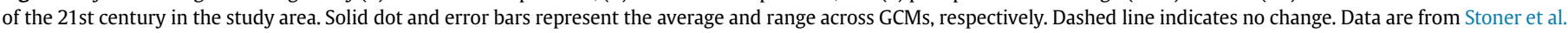
(2012).

Table 1

Overview of all longleaf pine dynamics scenarios modeled.

\begin{tabular}{|c|c|c|c|c|c|}
\hline Scenario & $\begin{array}{l}\text { Question } \\
\text { addressed }^{\mathrm{a}}\end{array}$ & $\begin{array}{l}\text { Emissions } \\
\text { scenario }^{\mathrm{b}}\end{array}$ & $\begin{array}{l}\text { Urbanization } \\
\text { included }^{c}\end{array}$ & $\begin{array}{l}\text { Annual area } \\
\text { burned }^{\mathrm{d}}\end{array}$ & Management types $^{\mathrm{d}}$ \\
\hline 1. Baseline climate & 1 & $\mathrm{~N} / \mathrm{A}$ & No & $\mathrm{N} / \mathrm{A}$ & $\mathrm{N} / \mathrm{A}$ \\
\hline 2. Baseline climate + urbanization & 1 & $\mathrm{~N} / \mathrm{A}$ & Yes & $\mathrm{N} / \mathrm{A}$ & $\mathrm{N} / \mathrm{A}$ \\
\hline 3. B1 & 1 & B1 & No & $\mathrm{N} / \mathrm{A}$ & $\mathrm{N} / \mathrm{A}$ \\
\hline 4. B1 + urbanization & 1 & B1 & Yes & $\mathrm{N} / \mathrm{A}$ & $\mathrm{N} / \mathrm{A}$ \\
\hline 5. A1FI & 1 & A1FI & No & $\mathrm{N} / \mathrm{A}$ & $\mathrm{N} / \mathrm{A}$ \\
\hline 6. A1FI + urbanization & 1 & A1FI & Yes & $\mathrm{N} / \mathrm{A}$ & $\mathrm{N} / \mathrm{A}$ \\
\hline 7. A1FI + maintenance burning & 2 & A1FI & No & Recent level & Maintenance burning \\
\hline 8. A1FI + urbanization + maintenance burning & 2 & A1FI & Yes & Recent level & Maintenance burning \\
\hline 9. A1FI + maintenance burning $\times 2$ & 2 & A1FI & No & $2 \times$ recent level & Maintenance burning \\
\hline $\begin{array}{l}\text { 10. } \mathrm{A} 1 \mathrm{FI}+\text { urbanization }+ \text { maintenance } \\
\text { burning } \times 2\end{array}$ & 2 & A1FI & Yes & $2 \times$ recent level & Maintenance burning \\
\hline 11. A1FI + management portfolio & 2 & A1FI & No & Recent level & $\begin{array}{l}\text { Maintenance, improvement, } \\
\text { restoration }\end{array}$ \\
\hline 12. A1FI + urbanization + management portfolio & 2 & A1FI & Yes & Recent level & $\begin{array}{l}\text { Maintenance, improvement, } \\
\text { restoration }\end{array}$ \\
\hline 13. A1FI + management portfolio $\times 2$ & 2 & A1FI & No & $2 \times$ recent level & $\begin{array}{l}\text { Maintenance, improvement, } \\
\text { restoration }\end{array}$ \\
\hline $\begin{array}{l}\text { 14. A1FI }+ \text { urbanization }+ \text { management } \\
\text { portfolio } \times 2\end{array}$ & 2 & A1FI & Yes & $2 \times$ recent level & $\begin{array}{l}\text { Maintenance, improvement, } \\
\text { restoration }\end{array}$ \\
\hline
\end{tabular}

a Question 1 addresses the effects of urbanization and climate change on the fire regime, while question 2 addresses the potential for management to achieve conservation goals for the longleaf pine ecosystems.

b A1FI is a high greenhouse gas emissions scenario; B1 is a low greenhouse gas emissions scenario.

c If urbanization was included, rates were based on urbanization projections by Terando et al. (2014).

d See Table 3 for target areas included for management actions in each scenario. 
types of prescribed burning applied, but all assumed wildfires would be affected by the A1FI climate trajectory because A1FI most closely approximates current GHG emissions levels. The eight scenarios included four scenarios with urbanization and four scenarios without urbanization. Those scenarios incorporated two levels of total annual area treated by prescribed burning: (1) a continuation of recent annual prescribed burning levels, and (2) a doubling of recent levels, which is the recommended strategy for conservation of the longleaf pine ecosystem (America's Longleaf, 2009).

Our management scenarios also varied in the allocation of prescribed burning to different purposes. One allocation assumed all prescribed burning would be allocated to maintaining open longleaf stands (hereafter, "maintenance"). The other was a portfolio approach, which allocated half of management toward maintenance, with the other half evenly split between improvement of degraded longleaf stands ("improvement") and restoration of non-longleaf stands such as pine plantations and agricultural lands that occur on soils suitable for longleaf ("restoration"). We provide details about how we modeled these management actions below in Section 2.3. Recent research as well as conservation plans for the longleaf pine ecosystem recommend using prescribed burning in all three of these ways, but prioritize maintenance (Mitchell et al., 2009; America's Longleaf, 2009).

\subsection{Simulation model with prescribed burning and urban growth}

To model scenarios of longleaf pine dynamics, we used a stateand-transition simulation model (STSM) developed with ST-Sim software version 2.0.1 (http://www.apexrms.com), which is an updated version of the Vegetation Dynamics Development Tool
(ESSA Technologies Ltd. 2007). We implemented ST-Sim in a way that is typical of other uses of VDDT and other STSMs (Provencher et al., 2007; Costanza et al., 2012; Kerns et al., 2012). Two major inputs are required for all STSMs: a state-and-transition model for each vegetation type simulated, and the initial conditions for the simulation, defined in terms of the proportion of the landscape in each vegetation type and state class. A vegetation type modeled in an STSM has distinct vegetation state classes that are defined by characteristics such as successional stage (e.g. early, mid- and latesuccession) and structure (e.g. amount of canopy). Transitions among state classes in the same vegetation type or in different vegetation types occur due to succession, disturbance, urbanization, or management actions, and are simulated in a semi-Markov framework on an annual time step. Successional transitions from one state class to another are deterministic, and the timing of succession depends only on the time spent in the state class. Urbanization, disturbances such as wildfires, and management actions occur according to user-defined probabilities or annual area targets that can vary among state classes.

We developed a state-and-transition simulation model for the longleaf pine ecosystem. Our model distinguished five longleaf pine state classes based on their successional stage and canopy structure and incorporated wildfires, prescribed fires, and other forest management (Table 1; Fig. 3). This model was modified from the East Gulf Coastal Plain Interior Upland Longleaf Pine Woodland ecosystem state-and-transition model produced by LANDFIRE (Outcalt, 2007; Rollins, 2009). The original state-and-transition model includes state classes, successional pathways and wildfire transitions, and was created to represent pre-European settlement dynamics. We adjusted wildfire probabilities to reflect recent fire regimes, and added transitions for thinning, harvest, urbanization, and prescribed fire.

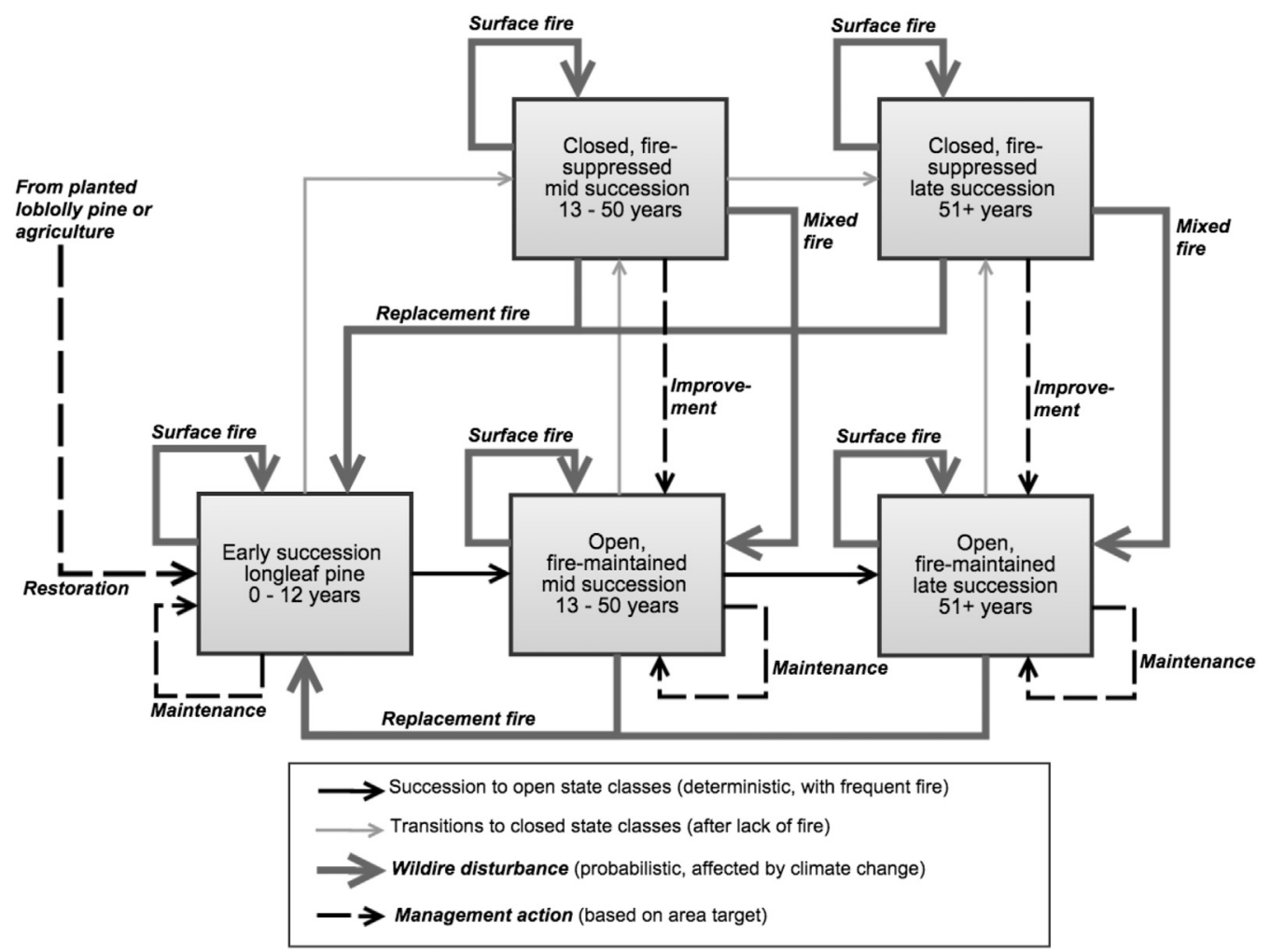

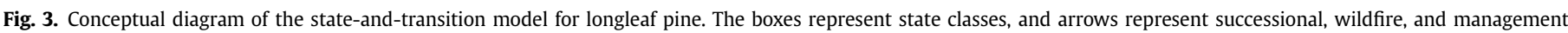

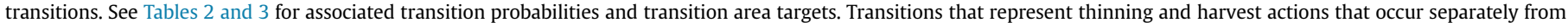

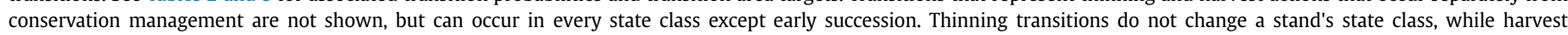
transitions any stand to early succession. 
In the original model, a longleaf pine stand begins in the early succession state class and stays in that state class until age 12, after which it can follow one of two successional pathways (Fig. 3). If wildfire or prescribed fire occurs in the early succession state class, a stand follows the "open", or fire-maintained, pathway, and will transition to mid-succession open state class from years 13-50, followed by the late-succession open state class after year 51 (Fig. 3). This successional pathway is the default, deterministic pathway, and depends only on the age of the stand. If a stand is not burned during early succession it follows the "closed" or firesuppressed pathway. Accordingly, it will transition to the midsuccession closed state class in years 13-50 and finally the latesuccession closed state class after year 51 (Fig. 3). Stands in the open state classes have hardwood cover $<10 \%$ in the midstory and $<15 \%$ in the overstory, while stands in the closed state classes have greater hardwood cover (Outcalt, 2007). Stands can experience surface, mixed-severity, or replacement wildfires. These fires serve to maintain canopy characteristics, transition a stand in a closed state class to an open state class, or transition a stand to the early succession state class (Table 2; Fig. 3). See Outcalt (Outcalt, 2007) for more details about the wildfire and successional dynamics in the model.
We added transitions to the state-and-transition model to represent the three roles of prescribed burning in our scenarios: maintenance, improvement, and restoration (Fig. 3). Maintenance of open longleaf pine stands is largely accomplished via lowseverity burns in open and early-succession stands in order to maintain the open structure. In our state-and-transition model, a maintenance prescribed burn keeps a stand in the early state class or one of the open state classes, and prevents it from transitioning to one of the closed state classes. Improvement and restoration represent aggregates of management actions that result in conversion to stands with longleaf pine as the dominant tree species and an open understory that contains a representative assemblage of native plants. Improvement of degraded longleaf pine involves restoring the fire regime to long-unburned stands, which usually have a buildup of vegetation or woody material in the midstory and understory (Varner et al., 2005). The proper management actions for improvement of longleaf is an area of active study, but the latest research suggests that an open structure and herbaceous understory can be achieved with three to four burns conducted two to three years apart (Outcalt and Brockway, 2010). Accordingly, improvement transitions in our model do not signify single burns; rather, they represent the aggregation of a series of burns over

Table 2

State classes, disturbance and management transitions ${ }^{\mathrm{a}}$ in the baseline scenario.

\begin{tabular}{|c|c|c|c|c|c|c|c|}
\hline From state class & Transition & To state class & Prob & Prop & Min age & Max age & $\mathrm{TSD}^{\mathrm{b}}$ \\
\hline \multirow[t]{5}{*}{ Early succession longleaf } & Surface wildfire $^{c}$ & Early longleaf & 0.024 & 1.00 & 0 & 12 & 0 \\
\hline & Replacement wildfire $^{c}$ & Early longleaf & 0.0007 & 1.00 & 0 & 12 & 0 \\
\hline & Maintenance prescribed fire ${ }^{\mathrm{d}}$ & Early longleaf & $1.00^{\mathrm{e}}$ & 1.00 & 0 & 12 & 0 \\
\hline & Alternative succession & Closed mid longleaf & 1.00 & 1.00 & 0 & 12 & $>10$ \\
\hline & Urbanization & Urban & 0.0018 & 0.00 & 0 & 12 & 0 \\
\hline \multirow[t]{7}{*}{ Closed, mid-succession longleaf } & Surface wildfire ${ }^{c}$ & Closed mid longleaf & 0.007 & 1.00 & 13 & 50 & 0 \\
\hline & Mixed-severity wildfire $^{c}$ & Open mid longleaf & 0.0007 & 1.00 & 13 & 50 & 0 \\
\hline & Replacement wildfire $^{c}$ & Early longleaf & 0.0006 & 1.00 & 13 & 50 & 0 \\
\hline & Improvement & Open mid longleaf & $1.00^{\mathrm{e}}$ & 1.00 & 13 & 50 & 0 \\
\hline & Thinning $^{\mathrm{a}}$ & Open mid longleaf & 0.012 & 1.00 & 13 & 50 & 0 \\
\hline & Harvest $^{\mathrm{a}}$ & Early longleaf & 0.006 & 1.00 & 30 & 50 & 0 \\
\hline & Urbanization & Urban & 0.0018 & 0.00 & 13 & 50 & 0 \\
\hline \multirow[t]{7}{*}{ Closed, late-succession longleaf } & Surface wildfire ${ }^{c}$ & Closed late longleaf & 0.007 & 1.00 & 51 & 999 & 0 \\
\hline & Mixed-severity wildfire ${ }^{c}$ & Open late longleaf & 0.0004 & 1.00 & 51 & 999 & 0 \\
\hline & Replacement wildfire $^{c}$ & Early longleaf & 0.007 & 1.00 & 51 & 999 & 0 \\
\hline & Improvement & Open late longleaf & $1.00^{\mathrm{e}}$ & 1.00 & 51 & 999 & 0 \\
\hline & Thinning ${ }^{\mathrm{a}}$ & Open late longleaf & 0.012 & 1.00 & 51 & 999 & 0 \\
\hline & Harvest $^{\mathrm{a}}$ & Early longleaf & 0.006 & 1.00 & 51 & 999 & 0 \\
\hline & Urbanization & Urban & 0.0018 & 0.00 & 51 & 999 & 0 \\
\hline \multirow[t]{7}{*}{ Open, mid-succession longleaf } & Surface wildfire ${ }^{c}$ & Open mid longleaf & 0.024 & 1.00 & 13 & 50 & 0 \\
\hline & Replacement wildfire $^{c}$ & Early longleaf & 0.0006 & 1.00 & 13 & 50 & 0 \\
\hline & Maintenance prescribed fire ${ }^{\mathrm{d}}$ & Open mid longleaf & $1.00^{\mathrm{e}}$ & 1.00 & 13 & 50 & 0 \\
\hline & Thinning ${ }^{\mathrm{a}}$ & Open mid longleaf & 0.012 & 1.00 & 13 & 50 & 0 \\
\hline & Harvest $^{\mathrm{a}}$ & Early longleaf & 0.006 & 1.00 & 30 & 50 & 0 \\
\hline & Alternative succession & Closed mid longleaf & 1.00 & 1.00 & 13 & 50 & $>10$ \\
\hline & Urbanization & Urban & 0.0018 & 0.00 & 13 & 50 & $>10$ \\
\hline \multirow[t]{7}{*}{ Open, late-succession longleaf } & Surface wildfire $^{c}$ & Open late longleaf & 0.024 & 1.00 & 51 & 999 & 0 \\
\hline & Replacement wildfire ${ }^{c}$ & Early longleaf & 0.0006 & 1.00 & 51 & 999 & 0 \\
\hline & Maintenance prescribed fire ${ }^{\mathrm{d}}$ & Open late longleaf & $1.00^{\mathrm{e}}$ & 1.00 & 51 & 999 & 0 \\
\hline & Thinning ${ }^{\mathrm{a}}$ & Open late longleaf & 0.012 & 1.00 & 51 & 999 & 0 \\
\hline & Harvest $^{\mathrm{a}}$ & Early longleaf & 0.006 & 1.00 & 51 & 999 & 0 \\
\hline & Alternative succession & Closed late longleaf & 1.00 & 1.00 & 51 & 999 & $>15$ \\
\hline & Urbanization & Urban & 0.0018 & 0.00 & 51 & 999 & 0 \\
\hline \multirow[t]{2}{*}{ Planted loblolly pine } & Restoration (success) ${ }^{\mathrm{d}}$ & Early longleaf & $1.00^{\mathrm{e}}$ & 0.85 & 0 & 999 & 0 \\
\hline & Urbanization & Urban & 0.0018 & 0.00 & 0 & 999 & \\
\hline \multirow[t]{2}{*}{ Agriculture } & Restoration (success) ${ }^{\mathrm{d}}$ & Early longleaf & $1.00^{\mathrm{e}}$ & 0.47 & 0 & 999 & 0 \\
\hline & Urbanization & Urban & 0.0018 & 0.00 & 0 & 999 & 0 \\
\hline
\end{tabular}

a Thinning and harvest probabilities are from the FIA database (USDA Forest Service, 2010).

b TSD stands for "time since disturbance" and is the time steps needed following a disturbance for the event to occur.

c LANDFIRE model probabilities (Outcalt, 2007) were calibrated to match recent wildfire records.

d Successful restoration on planted pine sites is the proportion of successful establishment of longleaf pine (Jose et al., 2010; Hu et al., 2012). Successful restoration of

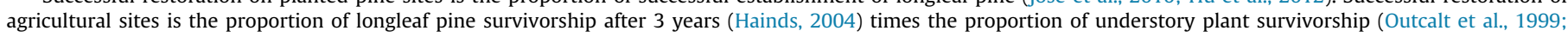

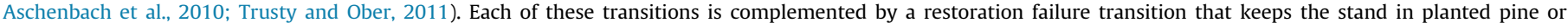
agriculture.

${ }^{\mathrm{e}}$ Indicates the transition was modeled using an area target that varied by scenario, instead of a probability. See Table 3 for area targets. 
several years. Improvement transitions in our model change the condition of longleaf from a closed state class to an open state class.

Restoration of longleaf pine on non-longleaf sites is done primarily on pine plantations and agricultural lands, and involves a combination of a series of burns, as well as other actions such as harvest and thinning, depending on the site (Johnson and Gjerstad, 2006). Pine plantations and agricultural lands make up much of the study area, as well as the Southeast as a whole, and thus are important targets for longleaf restoration (Johnson and Gjerstad, 2006). We simulated restoration of loblolly pine stands by adding two state classes to our model to represent planted loblolly pine and agriculture that occur on soil types that are suitable for longleaf. Restoration of longleaf on former agricultural areas and managed pine plantations is also a field of active research and involves a series of management actions. On former pine plantations, restoration of early-succession longleaf pine can be accomplished by a total of four prescribed burns at two- to three-year intervals, along with thinning, harvest of planted pine trees, and subsequent planting of longleaf (Johnson and Gjerstad, 2006). Similarly, restoration of agricultural land to early-succession longleaf can be accomplished with intensive site preparation, planting of longleaf trees, planting of understory herbaceous species, and prescribed burning to eliminate competition for longleaf and herbaceous species (Johnson and Gjerstad, 2006). Longleaf pine trees are difficult to regenerate on disturbed sites, and in fact, many early restoration efforts failed due to lack of regeneration of longleaf (Hainds, 2004; Brockway et al., 2006). We therefore included a probability of failure in our model.

To determine the total area of land that would be subject to prescribed burning in each of our scenarios, we gathered data on area of prescribed burns by county from state forestry offices in FL and GA (S. McLellan, Florida Division of Forestry, unpublished data; D. Chan, Georgia Forestry Commission, unpublished data). Prescribed burn records for AL were unavailable. We calculated the average proportion of FL and GA counties in the study area that burned annually for forest understory burning during 1994-2011, the period of time for which both states had data available. We used this calculated average annual area burned in the study area to develop target areas for all management transitions in our four modeled conservation scenarios, scaled by the area of longleaf in the landscape (Table 3).

\section{Table 3}

Area targets (ha) for prescribed burning transitions used in each scenario. For all scenarios that include management, the recent level of burning was used from the beginning of the simulation period. For scenarios that doubled the area burned, the higher values were used beginning in 2012. Pairs of scenarios differ in whether they incorporate urbanization, according to Table 1.

\begin{tabular}{|c|c|c|c|}
\hline Scenario & Maintenance & Improvement & Restoration \\
\hline $1 \& 2$. Baseline climate & $\mathrm{N} / \mathrm{A}$ & $\mathrm{N} / \mathrm{A}$ & $\mathrm{N} / \mathrm{A}$ \\
\hline $3 \& 4$. B1 climate & $\mathrm{N} / \mathrm{A}$ & $\mathrm{N} / \mathrm{A}$ & $\mathrm{N} / \mathrm{A}$ \\
\hline $5 \& 6$. A1FI climate & $\mathrm{N} / \mathrm{A}$ & $\mathrm{N} / \mathrm{A}$ & $\mathrm{N} / \mathrm{A}$ \\
\hline $7 \& 8 . \mathrm{A} 1 \mathrm{FI}+$ maintenance $^{\mathrm{a}}$ & 16,250 & 0 & 0 \\
\hline $9 \& 10 . \mathrm{A} 1 \mathrm{FI}+$ maintenance $\times 2$ & 32,500 & 0 & 0 \\
\hline $11 \& 12 . \mathrm{A} 1 \mathrm{FI}+$ portfolio $^{\mathrm{b}}$ & 8125 & 1160 & 1160 \\
\hline $13 \& 14 . \mathrm{A} 1 \mathrm{FI}+$ portfolio $\times 2^{\mathrm{b}}$ & 16,250 & 2320 & 2320 \\
\hline
\end{tabular}

a The total area burned in scenarios 7 and 8 is based on records of prescribed burns from Florida and Georgia, scaled by the proportion of the landscape that is currently in longleaf pine, and reduced by $28 \%$ to exclude the average proportion of burning that is conducted in the Southeast for slash reduction after logging (Haines et al., 2001).

b In each scenario that includes a portfolio of burning, half of the total area treated annually is used for maintenance, while the other half is divided between improvement and restoration. The area actually being improved or restored annually is reduced by a factor of 3.5 because those transitions represent the aggregate of three to four burns two to three years apart.
We used the results of a regional urbanization model to model future urbanization (Terando et al., 2014). First, we added a state class to the model to represent urban land. We then added probabilistic transitions to this new state class from every other longleaf pine, loblolly, and agricultural state in the model. The urbanization probability in our model was set to reflect the 95th percentile of the projected average annual urbanization rate through the 21 st century.

Finally, we added transitions to the longleaf pine state-andtransition model to represent thinning and harvesting of trees in all state classes except early succession (Table 2). These transitions represent management actions in some longleaf stands that are not associated with conservation management. Thinning transitions do not change a stand's state class, while harvest actions will transition any stand to early succession. We calculated annual probabilities for thinning and harvesting based on data from the USDA Forest Service Forest Inventory and Analysis database (USDA Forest Service, 2011).

\subsection{Wildfire probabilities and the effect of climate change}

We used a two-step approach to update wildfire probabilities for future climate scenarios: (1) calibrate model probabilities based on historic wildfire records; (2) incorporate the effects of projected climate changes on future wildfire probabilities. First, because the original LANDFIRE probabilities represented pre-European settlement conditions, and did not incorporate current passive and active fire suppression, we used recent wildfire records to adjust the wildfire probabilities in the longleaf pine model. We gathered wildfire records from state forestry offices in AL, FL and GA (B. Butler, Alabama Forestry Commission, unpublished data; S. McLellan, Florida Division of Forestry, unpublished data; D. Chan, Georgia Forestry Commission, unpublished data). The spatial and temporal resolution, and the attributes of these records varied by state. Data for some time periods and states contained geospatial location information, while other places and time periods summarized area burned across counties. Data for GA existed beginning in the early 1960s, while AL data were only available beginning in 2001. Therefore, we summarized all data across the minimum spatial resolution and time period of all three states: we calculated the total annual area burned per county for 2001-2010. We simulated longleaf pine dynamics under original LANDFIRE model probabilities for the first ten time steps, 2001-2010 and then compared the average annual area burned in the simulations with the average area burned in the wildfire records for the counties in the study area over the same period. We then scaled each wildfire probability in the LANDFIRE model by the change factor between simulated and recent wildfire areas. We used those calibrated probabilities as wildfire probabilities in the baseline climate scenario (Table 2).

Second, we incorporated the effects of climate changes on future wildfire probabilities under two GHG emissions scenarios. The two emissions scenarios, B1 and A1FI, respectively, represent a future where GHG emissions are either rapidly stabilized, or continue to grow similar to current rates (Nakićenović and Swart, 2000). As part of this study, an empirical model was developed to relate past local climate conditions to the area burned by wildfires in the coastal plain of Georgia (see Supplementary material). The relationship between past climate and area burned by wildfires was then used, to probabilistically project the area burned for the 21st century under the B1 and A1FI GHG emissions scenarios based on an ensemble of statistically downscaled climate projections (Stoner et al., 2012). We used these probabilistic projections of area burned to adjust wildfire probabilities in our state-and-transition model. For each of the GHG emissions scenarios, we took 50 samples across 
the probability density function for each projection year. We divided areas burned under climate change in each of the time series by the average area burned in the Georgia coastal plain from 2001 to 2011 to get a change factor in area burned for all future time steps. These were the values by which we multiplied wildfire probabilities in our state-and-transition simulation model (see Supplementary material for the probability multipliers). The 50 time series allowed us to run multiple Monte Carlo simulations for the A1FI and B1 scenarios.

\subsection{Initial model conditions}

To define the initial composition of longleaf pine, planted pine, agriculture, and urban areas in the study area, we used a polygon map of the region's land cover based on the 2001 Southeast GAP land cover map (Southeast Gap Analysis Project, 2008; see Costanza et al. (2012) for a description of methods). We included all longleaf and urban sites. However, we only included planted pine and agricultural sites that occurred on soils suitable for longleaf, based on soil survey data (Soil Survey Staff et al., 2014). We applied a series of automated and manual filters of the SSURGO data and soil series descriptions. We excluded soils whose descriptions or other characteristics indicated they were hydric, or that they did not meet the moisture and silt characteristics suitable for longleaf according to Peet (2006). Initializing the longleaf pine model also required defining the initial proportion of longleaf pine in each state class in the study area. Succession class (s-class) spatial data developed by LANDFIRE (LANDFIRE, 2013) assigns each $30 \mathrm{~m}$ pixel in the landscape to a state class from the LANDFIRE state-and-transition models. The s-class data are based on LANDFIRE vegetation height data, which has a spatial bias of $-3.8 \%$, and LANDFIRE cover data, which has an overall agreement of $74 \%$ when compared with field data across the U.S. (Toney et al., 2012). We used the s-class data to assign each longleaf pine polygon to a state class in our state-and-transition model according to a majority rule. We then summarized the proportion of longleaf in each of the state classes.

\subsection{Model output and data analysis}

We modeled the 14 wildfire and management scenarios using 50 Monte Carlo simulations over 99 time steps representing 2001-2099. To answer our first research question about the effect of climate change and the wildfire regime on the area of open longleaf, we calculated the area of longleaf burned by wildfires over time in the wildfire-only scenarios. For those scenarios, we also calculated the total area of all longleaf state classes over time in the scenarios that included wildfires only, compared with the initial conditions in the region. In addition to this total, we calculated the "ecological departure" of the landscape over time for the wildfireonly scenarios compared to initial conditions, after Low et al. (2010). Ecological departure compares the overall composition of state classes in the landscape through time to estimated preEuropean settlement conditions, which are often the goal of conservation for the longleaf pine ecosystem (VanLear et al., 2005; Frost, 2006; America's Longleaf, 2009). The percentage of the landscape that is ecologically departed $(D)$ for each time step was calculated for a given modeled scenario as:

$D=\left(1-\sum_{i=1}^{n} \min \left\{S_{i}, P_{i}\right\}\right) \times 100$

where $i$ is the longleaf pine state class, $S$ is the proportion of land in the state class for the projection, and $P$ is the proportion of land in the state class according to pre-European settlement conditions modeled by LANDFIRE (Outcalt, 2007; Rollins, 2009). Values of $D$ that are closer to 0 are less departed, while those close to 100 are more departed.

To answer our second question about the potential for management to achieve conservation goals in the longleaf ecosystem, for each of the management scenarios, we calculated the area of open longleaf, the total area of longleaf over time, and departure (D). We compared those values to the initial conditions in the region.

\subsection{Sensitivity analysis of alternative management strategies}

To evaluate more fully the range of outcomes from potential management scenarios, we conducted a sensitivity analysis of the two assumptions in our scenarios about which we were least certain: our assumptions about prescribed burning allocations and levels of burning. In addition to the scenarios discussed in Section 2.2 , we included scenarios that focused only on improvement or conversion, as well as those that assumed an even split in area among maintenance, improvement, and restoration. For each allocation, we modeled four levels of prescribed burning: recent level, 1.5, 2, and 3 times recent levels. The result was a total of 20 management scenarios consisting of five management regimes, each with four levels of management (see Supplementary material). We ran 50 Monte Carlo simulations of each of these scenarios.

\section{Results}

We identified 303,271 longleaf, suitable planted loblolly, and suitable agricultural polygons in the study area initially across $1,930,600$ ha ( $66 \%$ of the study area, see Fig. 1 ). We used those as the number of simulation cells and total landscape size, respectively, in ST-Sim, so simulation cells in ST-Sim had an area of 6.37 ha. Of the polygons we identified, 21,839 were longleaf pine (188,960 ha, $10 \%$ of the simulated area), 79,373 were planted pine (672,043 ha, $35 \%)$, and 195,723 were agriculture (1,069,608 ha, 55\%). Of the longleaf pine area in the initial landscape, $4 \%$ was classified as early succession, $74 \%$ had a closed structure, and $22 \%$ had an open structure. Mid-succession closed longleaf was the most common state, covering $70 \%$ of the longleaf pine area. Initially, the longleaf pine in the landscape was $62 \%$ departed. Simulation results showed relatively little variation across all 50 Monte Carlo iterations (see Supplementary material). Therefore, we averaged the results across the iterations, and present those averaged results below.

\subsection{Climate-wildfire scenarios}

Our comparison of recent wildfire occurrence data with a 10year simulation of longleaf pine dynamics from the original unmodified longleaf pine vegetation dynamics model showed that wildfires burned only $7.2 \%$ as much area as under presumed preEuropean settlement. The reduced probabilities resulted in modeled averages of 1578 ha and 1715 ha burning annually in the baseline climate scenarios with and without urbanization, respectively (Fig. 4). This represents an $8 \%$ reduction in annual wildfire area due to urban growth. In both cases, the area burned represented $0.9 \%$ of the longleaf pine, because urbanization also reduced the total area of longleaf in the landscape. In other words, on average without prescribed burning, a given longleaf pine polygon in our landscape experienced a wildfire every 111 years under both of these scenarios.

Under the four scenarios with climate change but no prescribed burning, the same annual proportion of longleaf burned annually on average as under the baseline scenarios (0.9\%), with a slightly 


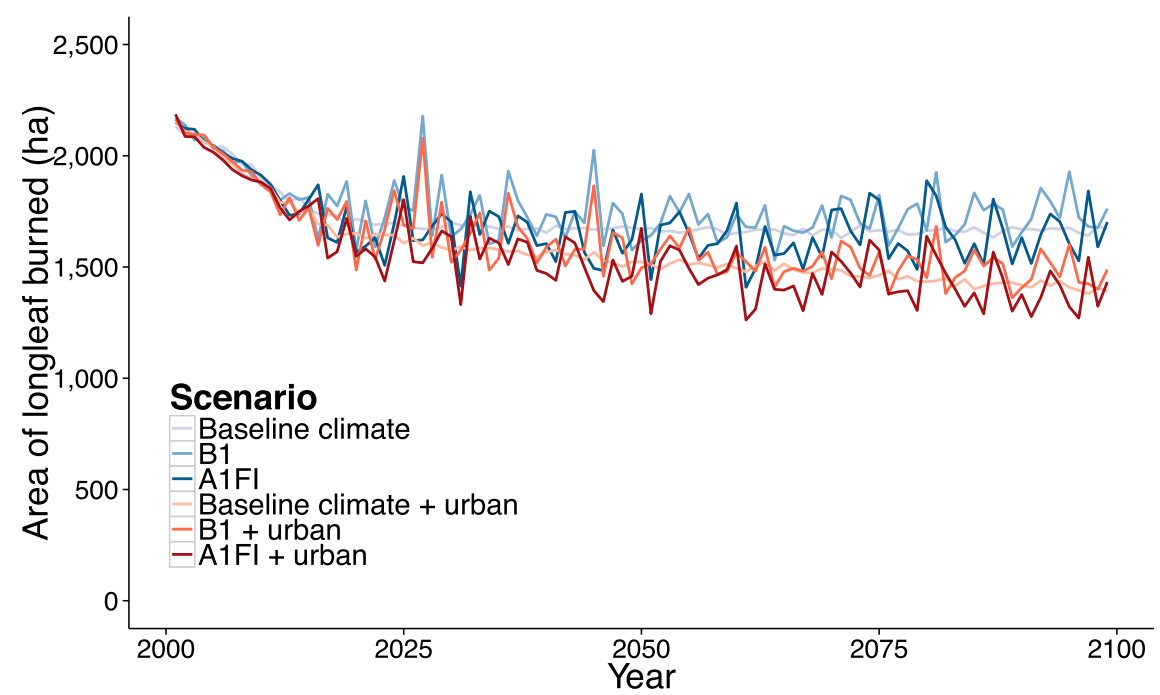

Fig. 4. Area of the landscape burned over time for the scenarios that incorporated the effect of climate on the wildfire regime only, without prescribed burning.

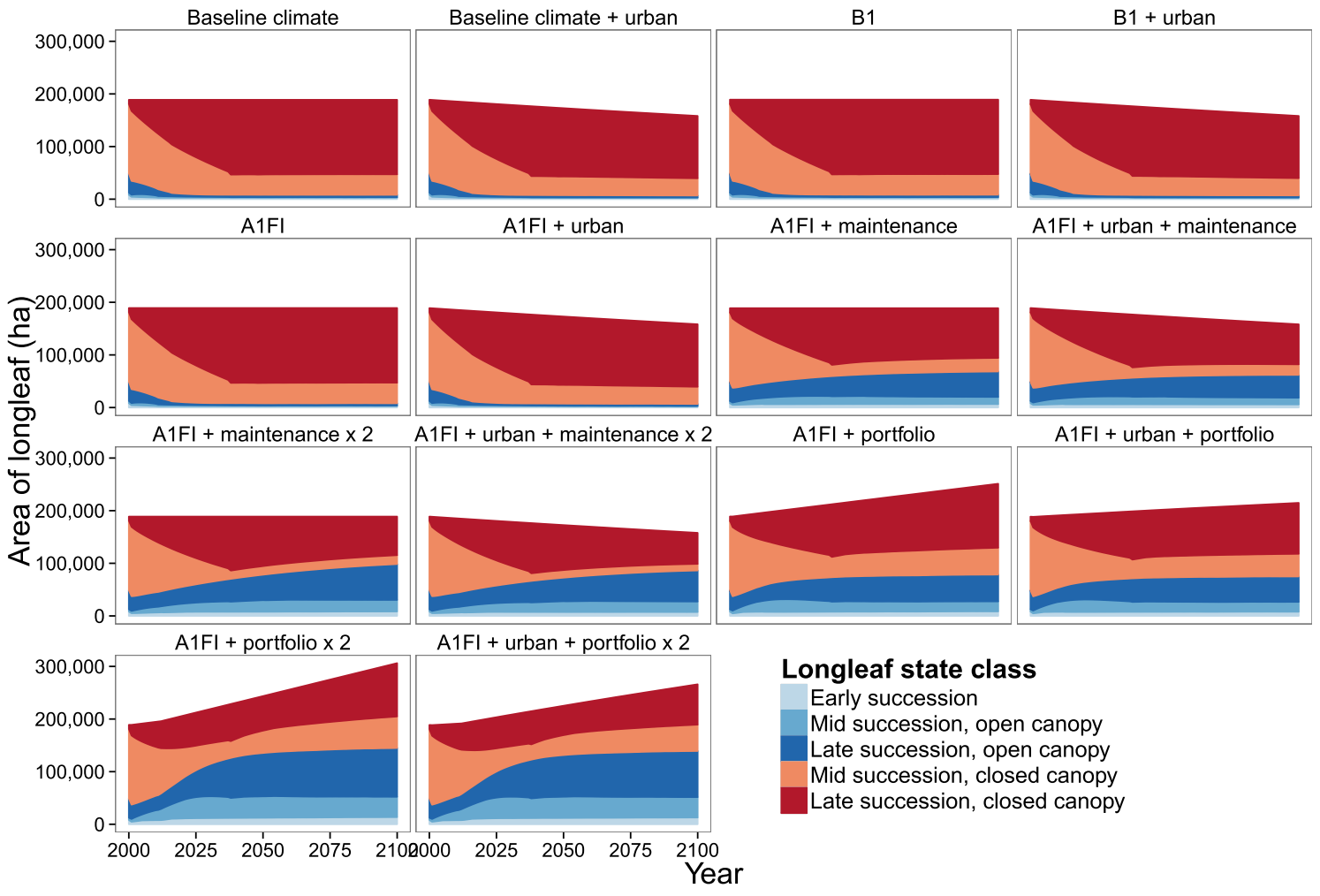

Fig. 5. Areas of longleaf pine in each state class over time for all modeled scenarios.

smaller total area burning over time in scenarios that included urbanization, especially toward the end of the century (Fig. 4). The small proportions of longleaf burned in all scenarios without prescribed fire led to a reduction in open canopy longleaf, and a buildup of closed canopy conditions across the simulation period in each case (Fig. 5). Compared with initial conditions, the simulated amount of open canopy longleaf in 2099 decreased by $89 \%$ in all of the climate change scenarios with urbanization, and $87 \%$ in scenarios without urbanization (Fig. 7). The modeled total amount of longleaf under these scenarios remained constant in scenarios without urbanization, and decreased $16 \%$ when urbanization was included (Fig. 7). Ecological departure showed nearly identical trajectories over time for all of these scenarios: in 2099, all had an ecological departure value of $76 \%$, an increase of $14 \%$ over the initial conditions (Fig. 6).

\subsection{Prescribed burning scenarios}

Each of the scenarios that included prescribed burning resulted in more open canopy longleaf (Figs. 5 and 7), and lower ecological departure (Fig. 6) over time than the scenarios that included wildfires only. However, the total area of longleaf varied depending on the allocation of burning and whether urbanization was included (Figs. 5 and 7). For pairs of scenarios with the same level 


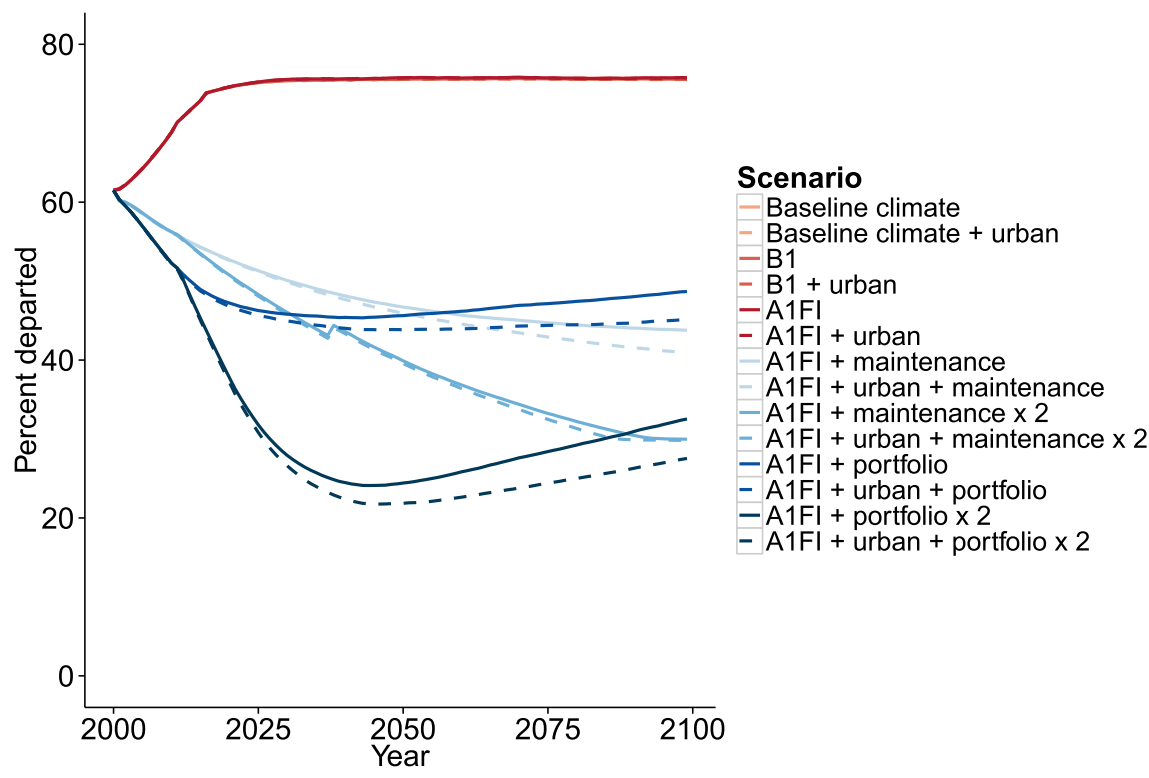

Fig. 6. Ecological departure over time for modeled scenarios. Scenarios without management have similar values over time, so their lines coincide on this graph.

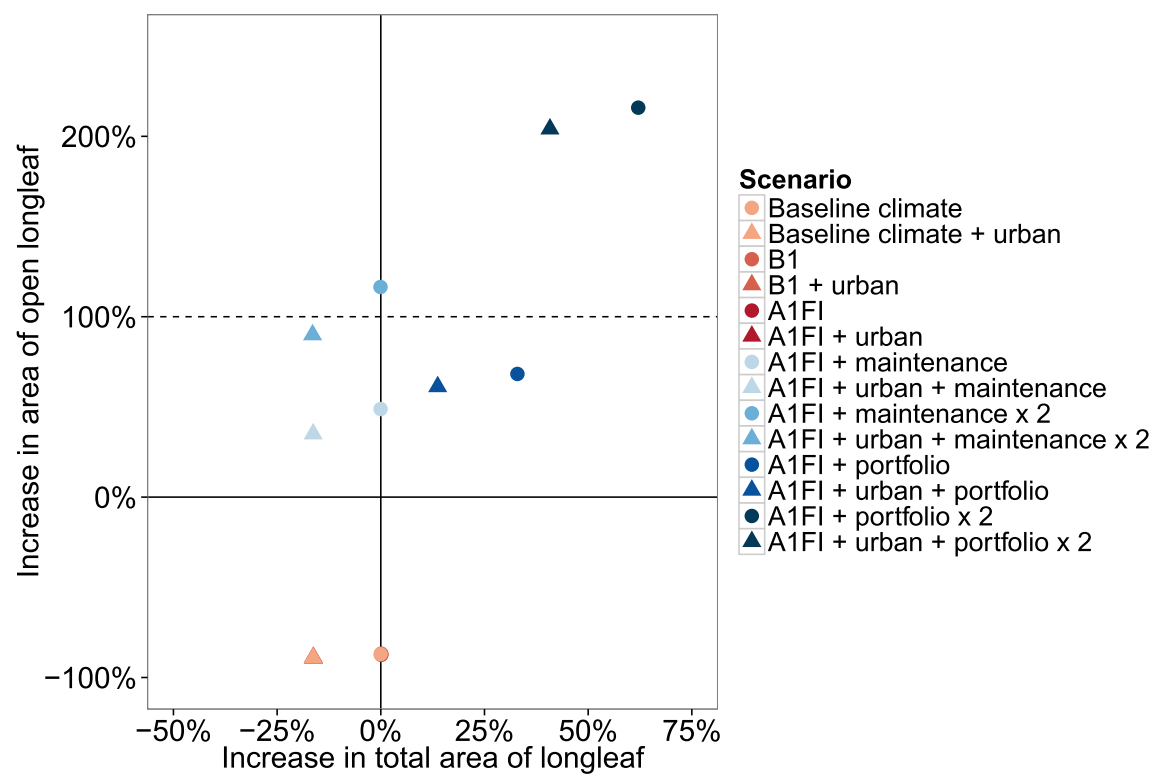

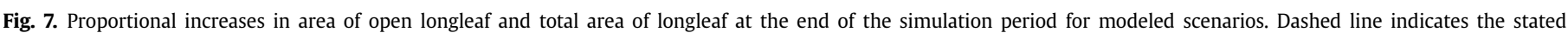

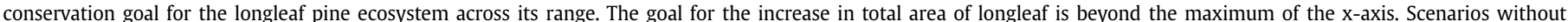

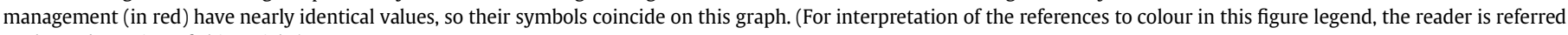
to the web version of this article.)

and allocation of burning, including urbanization always resulted in a lower ecological departure, but smaller areas of open and total longleaf (Figs. 6 and 7).

The area of open longleaf was greatest after 99 years in the scenarios that increased the overall annual area being burned (Fig. 7). In particular, the two scenarios that doubled burning and included a portfolio of burning actions resulted in more than a doubling of open longleaf: a $216 \%$ increase without urbanization, and a $204 \%$ increase when urbanization was included (Fig. 6). In fact, a doubling of open longleaf area was achieved under those scenarios by 2023. The scenario that doubled the area burned, focused on maintenance only also resulted in a projected doubling of the area of open longleaf, but that level of increase did not occur until 2078, and only when urbanization was not included.
Importantly, none of the scenarios we modeled resulted in a doubling of total longleaf area by 2099. The total area of longleaf increased only under scenarios that included a portfolio of burning actions, and did so even under urbanization (Figs. 5 and 7). As much as a $62 \%$ increase in the total area of longleaf was achieved, in the scenario that doubled prescribed burning without urbanization. Under scenarios that included maintenance burning only, the total area of longleaf remained constant over time without urbanization, and decreased with urbanization (Figs. 5 and 7).

The lowest ecological departure values resulted from scenarios that increased burning levels (Fig. 6). Specifically, the scenario that simulated increased burning with a portfolio of burning actions and urbanization had the lowest ecological departure across all time steps, and resulted in a final ecological departure of $28 \%$. The two 
scenarios that incorporated a doubling of burning with a focus on maintenance only resulted in the next lowest departure values (30\% with and without urbanization). A comparison of the scenarios that incorporated recent levels of burning shows that at the beginning of the simulation period, including a portfolio of prescribed burning actions resulted in lower ecological departure, while by 2099, the scenarios that incorporated maintenance burning only had lower departure.

\subsection{Sensitivity analysis of alternative management strategies}

Our sensitivity analysis shows that both the amount and allocation of burning influences the trajectory of the longleaf pine ecosystem under the A1FI climate scenario and urbanization (see Supplementary material). Generally, for a given allocation of burning, as the total annual area of burning increased, the final area of open longleaf increased and the final ecological departure decreased. Scenarios that incorporated a portfolio of burning actions (maintenance, improvement, and restoration), whether weighted toward maintenance or split evenly between the three, generally had the lowest levels of ecological departure and largest increases in open longleaf. The scenarios that focused on restoration only had the largest proportional increases in total area of longleaf, but much of that increase was in the closed canopy state. High levels of burning with a portfolio allocation generally resulted in the largest proportional increases in open canopy longleaf by the end of the simulation period. Importantly, by the end of the $21 \mathrm{st}$ century, some scenarios we modeled were able to meet the conservation goal for either the increase in total longleaf area (restoration-only scenarios that increased burning by at least $50 \%$ ) or increase in open longleaf (most other scenarios that increased burning by at least $50 \%$ ), but no scenario was able to meet both goals.

\section{Discussion}

We simulated the future dynamics of the longleaf pine ecosystem to evaluate whether conservation goals for the ecosystem are achievable in the face of climate change and urbanization. Importantly, our results: (a) demonstrate that urbanization is likely a bigger threat than climate change in this ecosystem over the 21st century; (b) emphasize the importance of management via prescribed burning for increasing the area of open longleaf pine as well as the total area of longleaf, and decreasing ecological departure of the ecosystem; and (c) show that an increase in level of prescribed burning can achieve the goal of doubling open longleaf pine relatively quickly, even if recent rates of urbanization continue.

Without prescribed burning, regardless of whether climate change and urban growth occur, our models indicate that over time, lack of fire is likely to cause a buildup of late-succession, closedcanopy longleaf pine. Under these scenarios, the simulated area of open longleaf decreased, and the ecological departure of the longleaf pine ecosystem increased. These trends were nearly identical for the two climate change scenarios and one baseline climate scenario we considered, indicating that climate change will have little effect on the trajectory of the longleaf pine ecosystem over the current century. This stationary climate-fire pattern is primarily due to the projected stability of the overall moisture availability. Precipitation deficits and the diurnal temperature range (which is related to moisture availability) remain steady in the climate change scenarios, which dampens the potential for increased drying and fire risk that would otherwise accompany the projected warming. Urbanization did have an effect on the ecosystem in these scenarios by decreasing both the area burned by fire and the area of total longleaf on the landscape. Therefore, if recent rates of urbanization continue, urban growth will likely impact the fire regime, and thus conservation and management of the longleaf pine ecosystem.

The result that alternative GHG emissions scenarios had little effect on wildfires in the longleaf pine ecosystem differs from some recent studies on the climate-wildfire relationship in the Southeast. Most notably, recent work by Stanturf and Goodrick (Stanturf and Goodrick, 2013) suggest that an increase in drier years, as is predicted by some climate models for some GHG emissions scenarios, will extend the spring wildfire season and lead to a slight increase in wildfire frequency compared with a future under no climate change. These results varied widely depending on the climate model and GHG emissions scenario used, and highlight the variability among projections of climate-driven processes in the region. Indeed, global GHG emissions are already exceeding the emissions levels in the A1FI scenario that we used, so our projections of the effects of climate change on wildfires may be conservative. Nonetheless, because the majority of wildfires are suppressed in the Southeast (Wade et al., 2000), even a small increase in area burned by wildfires due to climate change likely will not qualitatively change the trajectory of the longleaf pine ecosystem.

Our result that climate change will have little influence on wildfires in the longleaf pine ecosystem, combined with additional recent evidence that a changing climate is likely to have neutral or positive impacts on longleaf pine trees themselves, indicates that the longleaf pine ecosystem may be relatively resilient to climate change. For example, in part because longleaf pine trees are tolerant of drought and heat stress (Samuelson et al., 2012), most climate envelope models agree that longleaf pine may become more dominant across its range, and its range may expand northward (Prasad et al., 2007). Therefore, promoting establishment of the ecosystem may facilitate climate change adaptation in places where other ecosystems or species may be negatively affected by changing climate. This idea is not new, and has been promoted elsewhere (Diop et al., 2009; America's Longleaf, 2009), but our research emphasizes that proper management with prescribed fire will be crucial for ensuring resilience of the ecosystem once reestablished.

When prescribed burning is applied to the longleaf pine ecosystem at an areal extent that matches or exceeds recent levels, our models suggest that open longleaf pine will become more common and the ecological departure of the ecosystem will decrease compared to both the contemporary landscape and the future under no management. However, the degree of change depends on the annual area burned, the allocation of burning actions, and whether or not urbanization occurs. In our results, increased burning led to more open longleaf and lower ecological departure than lower levels of burning. For a given level of burning, incorporating a portfolio of actions also resulted in more open longleaf and lower departure. Urbanization led to smaller increases in open longleaf habitat over time.

Our results suggest that achieving the conservation goal of doubling the area of open longleaf pine is achievable in the future if the annual area treated by burning doubles compared to recent levels, as is suggested by recent conservation plans for the ecosystem. In fact, if burning doubles and includes a portfolio of actions, doubling the extent of open longleaf is achievable relatively quickly, even in the face of urbanization. Thus, a substantial increase in habitat is achievable in the near future for the species that depend on open-canopy longleaf, including the 16 federally threatened or endangered plant species associated with the longleaf pine ecosystem for which fire suppression is cited as a reason for listing (VanLear et al., 2005). Concomitant with this increase in 
open habitat, ecological departure in the longleaf pine ecosystem as a whole could decrease to less than $30 \%$ under the same management scenarios. In other words, stated management strategies of increasing the area subject to prescribed burning and allocating efforts to maintaining, improving, as well as restoring longleaf should be successful in achieving one conservation goal: doubling the area of open longleaf.

While the condition of existing longleaf is likely to improve under many of the scenarios we modeled, our sensitivity analysis indicates that achieving the other conservation goal of increasing the total area of longleaf by $135 \%$ will require a substantial focus on restoration of longleaf on non-longleaf sites. This shift in focus is qualitatively different from the recommendations in recent conservation plans (Mitchell et al., 2009; America's Longleaf, 2009). In our results, even when the overall area burned increased four-fold, scenarios that allocated only a small proportion of burning to restoration were not able to achieve the conservation goal. Furthermore, no scenario we modeled in the sensitivity analysis achieved both conservation goals of increase in total longleaf and increase in open longleaf. Taken together, these results suggest that in order to achieve the two conservation goals, region-wide longleaf pine management efforts may need to increase the level of burning, focus the majority of burning on restoration, but also include some burning aimed at maintenance and improvement of longleaf.

Notably, in our results, while urbanization led to a smaller total area of longleaf and a smaller area of open longleaf, the ecological departure of the longleaf ecosystem as a whole was lower in scenarios that incorporated urbanization than in the same scenarios without urbanization. In the state-and-transition model, we assumed an equal proportion of all longleaf would be urbanized over time. Because the closed canopy classes were present to a greater extent on the landscape, they were urbanized to a greater degree than the open classes. The result was a higher proportion of longleaf remaining in open canopy classes remaining after urbanization, even though the total area of open longleaf decreased.

According to our simulations, urban growth impacts the area of longleaf burned by wildfires, as well as the conservation goals that can be achieved by prescribed burning. For scenarios that incorporated urban growth, we used recent urbanization projections that assume business-as-usual conditions wherein the dominant form of development is low-density and spatially extensive rather than high-density and spatially intensive (i.e. building out instead of building up). Other studies that cover the same temporal and geographic extents have shown lower rates of urbanization, likely at least partially because they assume urban growth rates will closely follow rates consistent with standard demographic growth models (Bierwagen et al., 2010; Radeloff et al., 2012; Sohl et al., 2014). Therefore, the business-as-usual projections that assume a continuation of current land-use policies may be a worst-case scenario for the region (Terando et al., 2014). The true future magnitude and effect of urban growth may be somewhere between our "urban" and "no-urban" scenarios. However, until current land use policies and patterns of sprawl change, urbanization is likely to continue along this business-as-usual trajectory.

Thus, focusing on policies that promote smarter urban growth, and facilitating the use of prescribed burning near rapidly urbanizing areas will be an important consideration for management and conservation of this ecosystem. To inform such policies, our work should be extended to include multiple alternative urban growth scenarios in simulations. In addition, future simulations should also incorporate the expansion of the wildland-urban interface (WUI), the area where developed land meets or intermixes with natural vegetation. In the WUI, implementing prescribed burning is more difficult than in non-WUI areas, and suppression of wildfires in the
WUI is necessarily greater (Wade and Mobley, 2007; Gill and Stephens, 2009; Costanza and Moody, 2011). By simulating the growth of the WUI, modeling could provide crucial information to managers who must implement burning there.

Conservation plans have called for an increase in prescribed burning, and our results show such an increase would benefit the ecosystem, even in the face of urbanization, especially if applied to restoration. But is such an increase realistic in the southeastern U.S.? Indeed, more prescribed burning is currently conducted in the Southeast than in any other region of the country (Haines et al., 2001). However, there are many constraints to implementing prescribed burns, especially near urban lands, including difficulty and risk of damage to health or property from burning in the WUI (Costanza and Moody, 2011). Smoke management regulations that have been implemented to ameliorate effects on air quality are one of the most important constrains on implementing burns (Costanza and Moody, 2011). Furthermore, using prescribed fire to improve or restore long-unburned stands can result in higher-intensity fires, making it more difficult to burn near urban areas (Varner et al., 2005). Therefore, as urbanized areas increase in the future, maintaining recent prescribed burning levels will become more difficult, and the doubled levels of prescribed burning included in some of our scenarios may be difficult to achieve. The best we may be able to hope for is a continuation of current burning levels throughout this century.

A body of research on the proper methods for restoration of longleaf pine on former agricultural fields and pine plantations is also developing, and has potential to improve restoration success rates on former agricultural lands (Hainds, 2004; Aschenbach et al., 2010). Because of these developments, an increase in prescribed burning as well as an increased focus on restoration could be feasible across the Southeast. Our research shows that if realized, such increases could well achieve stated conservation goals for the important longleaf pine ecosystem in the face of global climate change, and could lead to substantial improvements even under urbanization.

\section{Conclusion}

By incorporating the effects of climate change and urbanization on the wild and managed fire regimes in the longleaf pine ecosystem, this work provides critical information for management and conservation of that ecosystem. Our results show that if it continues at recent rates, urbanization is likely to be a bigger threat to the fire regime, and thus to the future of the ecosystem, than climate change. We found that under climate change alone, the goals outlined by the conservation community could still be met in the near term with intensive management. However, increasing, or even continuing intensive management of the longleaf pine ecosystem will be challenging, especially given future urbanization. A growing number of programs and mechanisms exist to help prescribed burn practitioners overcome challenges to prescribed burning, especially on private land. For example, the National Fish and Wildlife Foundation's Longleaf Stewardship Fund (http://www. nfwf.org/longleaf) and the USDA Natural Resource Conservation Service's Longleaf Pine Initiative were recently created specifically to address the goals of the Range-wide Conservation Plan for Longleaf Pine. These programs and others can facilitate management of the important longleaf pine ecosystem in the face of multiple drivers of change.

This work demonstrates the importance of accounting for multiple ecosystem drivers together for informing ecosystem management. In particular, it is often assumed that climate change will be an important driver of ecosystem change, while the effects of urbanization are often overlooked. Our research suggests that, in 
fact, the future effects of urbanization could outweigh the effects of climate change in some critically endangered ecosystems. Thus, management actions that focus on mitigating the effects of urbanization are likely to be more effective in promoting persistence within these ecosystems compared to actions that prioritize climate change adaptation. Accounting for multiple anthropogenic drivers of global change will be critical for the development of effective management strategies that foster resilience and sustainability in vulnerable ecosystems.

\section{Acknowledgments}

T. Earnhardt assisted with development of the initial conditions, and C. Belyea assisted with urbanization projection data. We thank V. Carver and two anonymous reviewers for helpful feedback on the manuscript. This research was supported by the Department of the Interior Southeast Climate Science Center Contract G11AC20524. This manuscript is submitted for publication with the understanding that the United States Government is authorized to reproduce and distribute reprints for Governmental purposes. Any use of trade, product, or firm names is for descriptive purposes only and does not imply endorsement by the U.S. government.

\section{Appendix A. Supplementary data}

Supplementary data related to this article can be found at http:// dx.doi.org/10.1016/j.jenvman.2014.12.032.

\section{References}

America's Longleaf, 2009. Range-wide Conservation Plan for Longleaf Pine. Available at: http://www.americaslongleaf.org (accessed March 2012).

Anderies, J.M., Katti, M., Shochat, E., 2007. Living in the city: resource availability, predation, and bird population dynamics in urban areas. J. Theor. Biol. 247, 36-49.

Aschenbach, T.A., Foster, B.L., Imm, D.W., 2010. The initial phase of a longleaf pinewiregrass savanna restoration: species establishment and community responses. Restor. Ecol. 18, 762-771.

Bierwagen, B.G., Theobald, D.M., Pyke, C.R., Choate, A., Groth, P., Thomas, J.V., Morefield, P., 2010. National housing and impervious surface scenarios for integrated climate impact assessments. Proc. Natl. Acad. Sci. U. S. A. 107, 20887-20892.

Brockway, D.G., Outcalt, K.W., Boyer, W.D., 2006. Longleaf pine regeneration ecology and methods. In: Jose, S., Jokela, E.J., Miller, D.L. (Eds.), The Longleaf Pine Ecosystem. Springer, New York, NY, USA, pp. 95-133.

Costanza, J.K., Hulcr, J., Koch, F.H., Earnhardt, T., Mckerrow, A.J., Dunn, R.R., Collazo, J.A., 2012. Simulating the effects of the southern pine beetle on regional dynamics 60 years into the future. Ecol. Model. 244, 93-103.

Costanza, J.K., Moody, A., 2011. Deciding where to burn: stakeholder priorities for prescribed burning of a fire-dependent ecosystem. Ecol. Soc. 16 (1), 14

Costanza, J.K., Weiss, J., Moody, A., 2013. Examining the knowing-doing gap in the conservation of a fire-dependent ecosystem. Biol. Conserv. 158, 107-115.

Dale, V.H., Joyce, L.A., Mcnulty, S., Neilson, R.P., Ayres, M.P., Flannigan, M.D., Hanson, P.J., Irland, L.C., Lugo, A.E., Peterson, C.J., Simberloff, D., Swanson, F.J., Stocks, B.J., Michael Wotton, B., 2001. Climate change and forest disturbances. BioScience 51, 723-734.

Diop, A., Palola, E., Staudt, A., Stein, B., 2009. Standing Tall: How Restoring Longleaf Pine Can Help Prepare the Southeast for Global Warming. National Wildlife Federation Report. Reston, VA, USA.

Environmental Protection Agency (EPA), 2004. Level III and IV Ecoregions of EPA Region 4. U.S. Environmental Protection Agency. National Health and Environmental Effects Research Laboratory, Western Ecology Division, Corvallis, OR, USA.

ESSA Technologies Ltd., 2007. Vegetation Dynamics Development Tool User Guide, Version 6.0. Prepared by ESSA Technologies Ltd., Vancouver, BC, Canada, p. 196 Available at: http://www.essa.com/documents/vddt/VDDT-60-User-Guide.pdf (accessed April 2014).

Frost, C.C., 1993. Four centuries of changing landscape patterns in the longleaf pine ecosystem. In: Hermann, S. (Ed.), Proceedings of the Tall Timbers Fire Ecology Conference, No. 18, The Longleaf Pine Ecosystem: Ecology, Restoration and Management. Tall Timbers Research Station, Tallahassee, FL, USA, pp. 17-43.

Frost, C.C., 2006. History and future of the longleaf pine ecosystem. In: Jose, S., Jokela, E., Miller, D. (Eds.), Longleaf Pine Ecosystems: Ecology, Management, and Restoration. Springer, New York, NY, USA, pp. 9-48.

Georgia Governor's Office of Planning and Budget, 2013. Georgia County Residential Population Projections 2012-2030. Available at: http://opb.georgia.gov/ population-projections (accessed January 2014)

Gill, A.M., Stephens, S.L., 2009. Scientific and social challenges for the management of fire-prone wildland-urban interfaces. Environ. Res. Lett. 4, 034014.

Grimm, N.B., Faeth, S.H., Golubiewski, N.E., Redman, C.L., Wu, J., Bai, X., Briggs, J.M. 2008. Global change and the ecology of cities. Science 319, 756-760.

Hainds, M.J., 2004. Establishing longleaf pine seedlings on agricultural fields and pastures. In: Connor, K.F. (Ed.), Proceedings of the 12th Biennial Southern Silvicultural Research Conference. U.S. Department of Agriculture, Forest Service, Southern Research Station, Asheville, NC, USA, pp. 309-313. Gen. Tech. Rep. SRS-71.

Haines, T.K., Busby, R.L., Cleaves, D.A., 2001. Prescribed burning in the South: trends, purpose and barriers. South. J. Appl. For. 25, 149-153.

Hawbaker, T., Radeloff, V., Stewart, S.I., Hammer, R.B., Keuler, N.S., Clayton, M.K. 2013. Human and biophysical influences on fire occurrence in the United States. Ecol. Appl. 23, 565-582.

Hu, H., Wang, G.G., Walker, J.L., Knapp, B.O., 2012. Silvicultural treatments for converting loblolly pine to longleaf pine dominance: effects on planted longleaf pine seedlings. For. Ecol. Manag. 276, 209-216.

IPCC, 2007. Climate change 2007: impacts, adaptation, and vulnerability. In: Parry, M.L., Canziani, O.F., Palutikof, P. van der L., Hansen, C.E. (Eds.), Contribution of Working Group II to the Fourth Assessment Report of the Intergovernmental Panel on Climate Change. Cambridge University Press, Cambridge, U.K., and New York, NY, USA, p. 976.

Johnson, R., Gjerstad, D., 2006. Restoring the overstory of longleaf pine ecosystems. In: Jose, S., Jokela, E.J., Miller, D.L. (Eds.), The Longleaf Pine Ecosystem: Ecology, Silviculture, and Restoration. Springer, New York, NY, USA, pp. 271-295.

Jose, S., Ranasinghe, S., Ramsey, C.L., 2010. Longleaf pine (Pinus palustris P. Mill.) restoration using herbicides: overstory and understory vegetation responses on a coastal plain flatwoods site in Florida, U.S.A. Restor. Ecol. 18, 244-251.

Kaza, N., 2013. The changing urban landscape of the continental United States. Landsc. Urban Plan. 110, 74-86.

Kerns, B.K., Shlisky, A.J., Daniel, C. (Eds.), 2012. Proceedings of the First Landscape State-and-transition Simulation Modeling Conference, June 14-16, 2011, Portland, Oregon, p. 215. USDA Forest Service Gen. Tech. Rep. PNW-GTR-869. Portland, OR, USA.

LANDFIRE, 2013. LANDFIRE 2010 (Version 1.2.0) Succession Class (S-class) Layer. U.S Department of Interior, Geological Survey. Available at: http://landfire.cr.usgs. gov/viewer (accessed March 2014).

Litschert, S.E., Brown, T.C., Theobald, D.M., 2012. Historic and future extent of wildfires in the Southern Rockies Ecoregion, USA. For. Ecol. Manag. 269, 124-133.

Low, G., Provencher, L., Abele, S.L., 2010. Enhanced conservation action planning: assessing landscape condition and predicting benefits of conservation strategies. J. Conserv. Plan. 6, 36-60.

Millar, C.I., Woolfenden, W.B., 1999. The role of climate change in interpreting historical variability. Ecol. Appl. 9, 1207-1216.

Mitchell, R., Engstrom, T., Sharitz, R., 2009. Old forests and endangered woodpeckers: old-growth in the southern coastal plain. Nat. Areas J. 29, 301-310.

Moritz, M., Parisien, M., Batllori, E., 2012. Climate change and disruptions to global fire activity. Ecosphere 3,1-22.

Nakićenović, N., Swart, R., 2000. Special Report on Emissions Scenarios: a Special Report of the Working Group III of the Intergovernmental Panel on Climate Change. Cambridge University Press, Cambridge, U.K.

Outcalt, K.W., 2007. LANDFIRE Biophysical Setting Model for East Gulf Coastal Plain Interior Upland Longleaf Pine Woodland. In: LANDFIRE Biophysical Setting Descriptions, Map Zone 55, pp. 39-44. Available at: http://www.landfire.gov/ national_veg_models_op2.php (accessed August 2013).

Outcalt, K.W., Brockway, D.G., 2010. Structure and composition changes following restoration treatments of longleaf pine forests on the Gulf Coastal Plain of Alabama. For. Ecol. Manag. 259, 1615-1623.

Outcalt, K.W., Williams, M.E., Onokpise, O., 1999. Restoring Aristida stricta to Pinus palustris ecosystems on the Atlantic Coastal Plain, U.S.A. Restor. Ecol. 7, $262-270$.

Overpeck, J.T., Rind, D., Goldberg, R., 1990. Climate-induced changes in disturbance and vegetation. Nature 343, 51-53.

Paveglio, T.B., Prato, T., Hardy, M., 2013. Simulating effects of land use policies on extent of the wildland urban interface and wildfire risk in Flathead County Montana. J. Environ. Manag. 130, 20-31.

Peet, R.K., 2006. Ecological classification of longleaf pine woodlands. In: Jose, S. Jokela, E., Miller, D. (Eds.), Longleaf Pine Ecosystems: Ecology, Management, and Restoration. Springer, New York, NY, USA, pp. 51-94.

Prasad, A.M., Iverson, L.R., Matthews, S., Peters, M., 2007. A Climate Change Atlas for 134 Forest Tree Species of the Eastern United States [database]. Northern Research Station, USDA Forest Service, Delaware, OH, USA. Available at: http:// www.nrs.fs.fed.us/atlas/tree (accessed May 2013).

Provencher, L., Forbis, T.A., Frid, L., Medlyn, G., 2007. Comparing alternative management strategies of fire, grazing, and weed control using spatial modeling. Ecol. Model. 209, 249-263.

Radeloff, V.C., Nelson, E., Platinga, A.J., Lewis, D.J., Helmers, D., Lawler, J.J. Withey, J.C., Beaudry, F., Martinuzzi, S., Butsic, V., Lonsdorf, E., White, D. Polasky, S., 2012. Economic-based projections of future land use in the conterminous United States under alternative policy scenarios. Ecol. Appl. 22, 1036-1049.

Rollins, M.G., 2009. LANDFIRE: a nationally consistent vegetation, wildland fire, and fuel assessment. Int. J. Wildland Fire 18, 235-249. 
Samuelson, L.J., Stokes, T.a., Johnsen, K.H., 2012. Ecophysiological comparison of 50year-old longleaf pine, slash pine and loblolly pine. For: Ecol. Manag. 274, 108-115.

Sohl, T., Sayler, K., Bouchard, M., 2014. Spatially explicit modeling of 1992 to 2100 land cover and forest stand age for the conterminous United States. Ecol. Appl. 24, 1015-1036.

Soil Survey Staff, Natural Resource Conservation Service, U.S. Department of Agriculture, 2014. Soil Survey Geographic (SSURGO) Database. Available online at: http://soildatamart.nrcs.usda.gov (accessed October 2014).

Southeast Gap Analysis Project (SEGAP), 2008. Southeast GAP Regional Land Cover [digital Data]. Available at: http://www.basic.ncsu.edu/segap/ (accessed June 2012).

Southeastern Regional Working Group, 2012. A National Cohesive Wildland Fire Strategy: Southeastern Regional Assessment. Available at: http://www forestsandrangelands.gov/strategy/reports.shtml (accessed December 2012).

Stanturf, J.A., Goodrick, S.L., 2013. Fire. In: Wear, D.N., Greis, J.G. (Eds.), The Southern Forest Futures Project: Technical Report. Gen. Tech. Rep. SRS-GTR-178. U.S. Department of Agriculture, Forest Service, Southern Research Station, Asheville, NC, USA, p. 542.

Staudt, A., Leidner, A.K., Howard, J., Brauman, K.a, Dukes, J.S., Hansen, L.J., Paukert, C., Sabo, J., Solórzano, L. a, 2013. The added complications of climate change: understanding and managing biodiversity and ecosystems. Front. Ecol. Environ. 11, 494-501.

Stein, B.a, Staudt, A., Cross, M.S., Dubois, N.S., Enquist, C., Griffis, R., Hansen, L.J., Hellmann, J.J., Lawler, J.J., Nelson, E.J., Pairis, A., 2013. Preparing for and managing change: climate adaptation for biodiversity and ecosystems. Front. Ecol. Environ. 11, 502-510.

Stephens, S.L., Agee, J.K., Fule, P.Z., North, M.P., Romme, W.H., Swetnam, T.W., 2013. Managing forests and fire in changing climates. Science 342, 41-42.

Stoner, A.M.K., Hayhoe, K., Yang, X., Wuebbles, D.J., 2012. An asynchronous regional regression model for statistical downscaling of daily climate variables. Int. J. Climatol. 33, 2473-2494.

Terando, A., Costanza, J.K., Belyea, C., Dunn, R.R., McKerrow, A.J., Collazo, J.A., 2014. The southern megalopolis: using the past to predict the future of urban sprawl in the Southeast U.S. PLOS One 9, e102261.

Toney, C., Peterson, B., Long, D., Parsons, R., Cohn, G., 2012. Development and applications of the LANDFIRE forest structure layers. In: Morin, R.S., Liknes, G.C. (Eds.), Moving from Status to Trends: Forest Inventory and Analysis (FIA) Symposium 2012; 2012 December 4-6; Baltimore MD. USDA Forest Service Northern Research Station GTR NRS-P-105, Newtown Square, PA, USA, pp. 305-309.

Trusty, J.L., Ober, H.K., 2011. Determinants of successful groundcover restoration in forests of the southeastern United States. J. Nat. Conserv. 19, 34-42.
Tu, J., 2013. Spatial variations in the relationships between land use and water quality across an urbanization gradient in the watersheds of Northern Georgia, USA. Environ. Manag. 51, 1-17.

U.S. Census Bureau, 2011. 2010 Demographic Profile Summary File Data for Alabama, Florida and Georgia. US Census Bureau. Available at: http://www2. census.gov/census_2010/03-Demographic_Profile/ (accessed January 2014).

U.S. Fish and Wildlife Service, 2003. Recovery Plan for the Red-cockaded Woodpecker (Picoides borealis): Second Revision, p. 296. Atlanta, GA, USA.

University of Alabama Center for Business and Economic Research (CBER), 2012 Alabama County Population Projections 2015-2040. Available at: http://cber. cba.ua.edu/edata/est_prj.html (accessed January 2014).

University of Florida Bureau of Economic and Business Research, 2013. Projections of Florida population by county, 2015-2040, with estimates for 2012. Fla. Popul. Stud. 46.

USDA Forest Service, 2010. Forest Inventory and Analysis Data. Washington, DC, USA. Available online at: http://www.fia.fs.fed.us/tools-data/default.asp (accessed August 2010)

USDA Forest Service, 2011. Forest Inventory and Analysis Data. Available at: http:// apps.fs.fed.us/fiadb-downloads/datamart.html (accessed July 2011).

VanLear, D.H., Carroll, W.D., Kapeluck, P.R., Johnson, R., 2005. History and restoration of the longleaf pine-grassland ecosystem: Implications for species at risk. For. Ecol. Manag. 211, 150-165.

Varner, J.M., Gordon, D.R., Putz, F.E., Hiers, J.K., 2005. Restoring fire to longunburned Pinus palustris ecosystems: novel fire effects and consequences for long-unburned ecosystems. Restor. Ecol. 13, 536-544.

Varner, J.M., Hiers, J.K., Ottmar, R.D., Gordon, D.R., Putz, F.E., Wade, D.D., 2007. Overstory tree mortality resulting from reintroducing fire to long-unburned longleaf pine forests: the importance of duff moisture. Can. J. For. Res. 37, 1349-1358.

Wade, D.D., Brock, B.L., Brose, P.H., Grace, J.B., Hoch, G.A., Patterson, W.A., 2000. Fire in eastern ecosystems. In: Brown, J.K., Smith, J.K. (Eds.), Wildland Fire in Ecosystems: Effects of Fire on Flora. Gen. Tech. Rep. RMRS-GTR-42, vol. 2. USDA Forest Service, Rocky Mountain Research Station, Ogden, UT, USA pp. 53-96.

Wade, D., Mobley, H., 2007. Managing Smoke at the Wildland-urban Interface. General Technical Report SRS-103. USDA Forest Service, Southern Reserach Station, Asheville, NC, USA, p. 40.

Westerling, A.L., Hidalgo, H.G., Cayan, D.R., Swetnam, T.W., 2006. Warming and earlier spring increase western U.S. forest wildfire activity. Science 313, 940-943. 